\title{
IMPLEMENTATION OF DPSIR FRAMEWORK IN THE MANAGEMENT OF THE ALMYROS BASIN, MAGNESIA PREFECTURE
}

\author{
Lyra A., Pliakas F., Skias S. and Gkiougkis I. \\ Engineering Geology Laboratory, Civil Engineering Department, Democritus University of \\ Thrace,67100Xanthi,Greece.lyra_km@hotmail.com,fpliakas@civil.duth.gr, \\ skias@civil.duth.gr,jgiougis@civil.duth.gr
}

\begin{abstract}
In this paper, the implementation of the framework DPSIR is presented in the coastal part of the Almyros Basin, Magnesia Prefecture. The procedure included the use of previous relevant geological, hydrological, hydrogeological and management studies, regarding the study area, the results of which are classified and assigned to the driving forces, pressures, states, impacts and responses of the DPSIR method for the area under investigation. The approach concluded to an interesting visualization of the current situation of the urban and natural environment of the study area, promoting the recognition of problems arising from the intervention of the human factor and directing environmental actions towards a rational water resources management in the wider region.
\end{abstract}

Keywords: Management of coastal hydrologic basins and aquifer systems, framework DPSIR, water resources.

\section{Пєрí $\eta \psi \eta$}

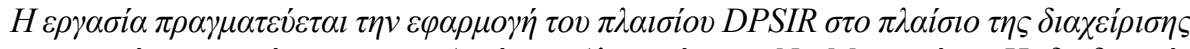

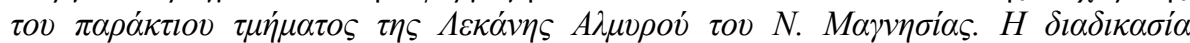

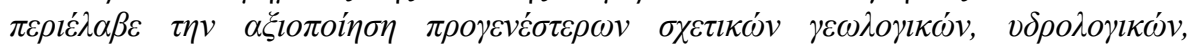

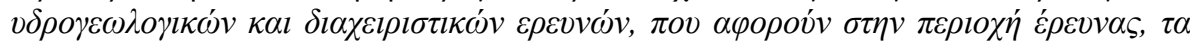

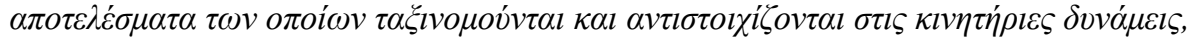

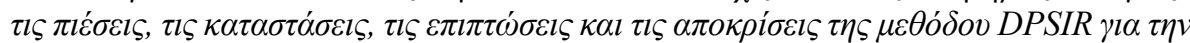

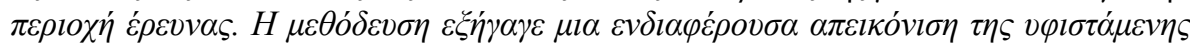

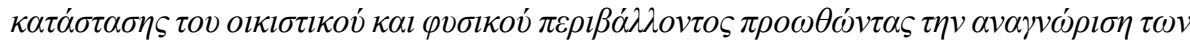

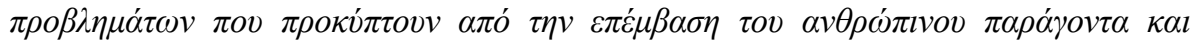

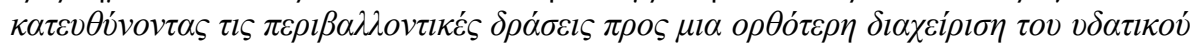

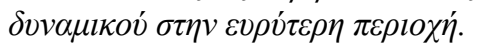

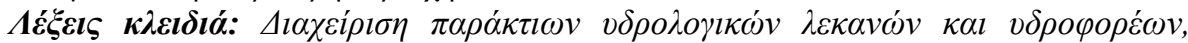

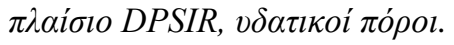

\section{Introduction}

Almyros basin (figure 1) comprises the southernmost part of the Almyros-Pelion streams' hydrological basin which belongs to the Thessaly water district. It exhibits an area of $856 \mathrm{~km}^{2}$, occupying the SE part of Thessaly and its limits are defined by the coastline of the Pagasitikos Gulf, the mountain range of Othrys (which is the eastern continuation of the Pindos mountain range) and the 
Chalkodonion or Mavrovouni Mountain. The geomorphology of the region is characterized by hilly terrain in the western parts, semi-mountainous with slope inclinations, following in general the direction of the faults (N-E). In the surrounding wider area, environmentally protected areas are encountered, included in the Natura 2000 network, the Corine Land Cover Programme and are characterized as landscapes and biotopes of outstanding natural beauty (Chouliaras, 2014; MEECC, 2014; Mentzafou, 2004).

Regarding the land use in the Almyros basin, there is intense agricultural and livestock activity, both in the plains and the higher parts of the basin. The local economy is mainly based on the primary sector. There also exists significant industrial status evident by the industrial area and the Industrial Park, located in the plain part of the basin. The wastewater treatment plant, located in the Almyros City area, serves the residents and the industrial units of the whole basin (Chouliaras, 2014; MEECC, 2014a).

The climate in this region is of Mediterranean type with dry and hot summers (Chouliaras, 2014). The mean monthly temperature and precipitation for the town of Almyros for the period 1990 - 2012 are shown in figure 2 .

\section{Geological and hydrogeological setting}

The geological formations structuring the Almyros basin, are distinguished into impermeable (flysch, crystalline-schists and volcanic rocks), semi-permeable (neogene sediments) and permeable formations (quaternary sediments and karstic limestones). In the margins of the coastal zone, the karstic rocks form very good aquifers, which recharge the overlying neogene and quaternary sediments of the region. A characteristic feature of carbonate rocks, close to the coastal zone, is their hydraulic communication with the sea resulting in the occurrence of salinization phenomena in the margins of this zone. The neogene sediments of the region exhibit limited areal spreading and are encountered to the northern and western parts of it; in fact, they are successions of various coarse soil materials (sandstones, gravel, semi-cohesive conglomerates) and fine ones (intercalations of clayey marls). Generally, the recharge of the neogene sediments is controlled by the periodic flow of the streams in this region, its carbonate masses and the tectonised-fractured crystalline rocks with which they come into contact, the overlying quaternary sediments, as well as by the atmospheric precipitations of the region. The recharge procedure of the quaternary sediments is mainly originated from atmospheric precipitations and locally from the carbonate rockmasses of the Othrys mountain range (Myriounis, 2008).

In the Almyros basin, four (4) groundwater systems are encountered, as it follows (MEECC, 2014b) (figure 1 left): (1) N. Anchialos - N. Ionia (granular - fractured - karstic) (GR0800280), (2) AlmyrosVelestino (fractured - karstic) (GR0800090), (3) Almiros (granular) (GR0800140) and (4) Othrys (fractured - karstic) (GR0800160). Alluvial aquifers with the largest thicknesses are encountered in the coastal part of the basin (MEECC, 2014c; Myriounis, 2008).

The particular piezometric conditions that exist in the area are manifested by the occurrence of submarine springs and artesian phenomena. These phenomena have been identified in both the southern and the northern part of the region. In the northern and southern part of the Efxinoupoli sub-basin, negative piezometric heads have been observed in areas where carbonates rocks with neogene and quaternary sediments are located. In the above areas, groundwater salinization phenomena are observed. In the Sourpi sub-basin, the declining water table of aquifers results in alternation of the recharge regime in the loose sediments, from west to east towards east to west. This phenomenon is attributed to the specific geological and tectonic conditions encountered in the region. In these areas, no negative piezometric heads are observed; however, groundwater intense salinization is observed due to the hydraulic communication of the carbonate rockmasses with the sea, the incorrect position in the mounting of the pump into the well borehole and the groundwater overexploitation in the region to cover the irrigation needs of its crops (Myriounis, 2008). 


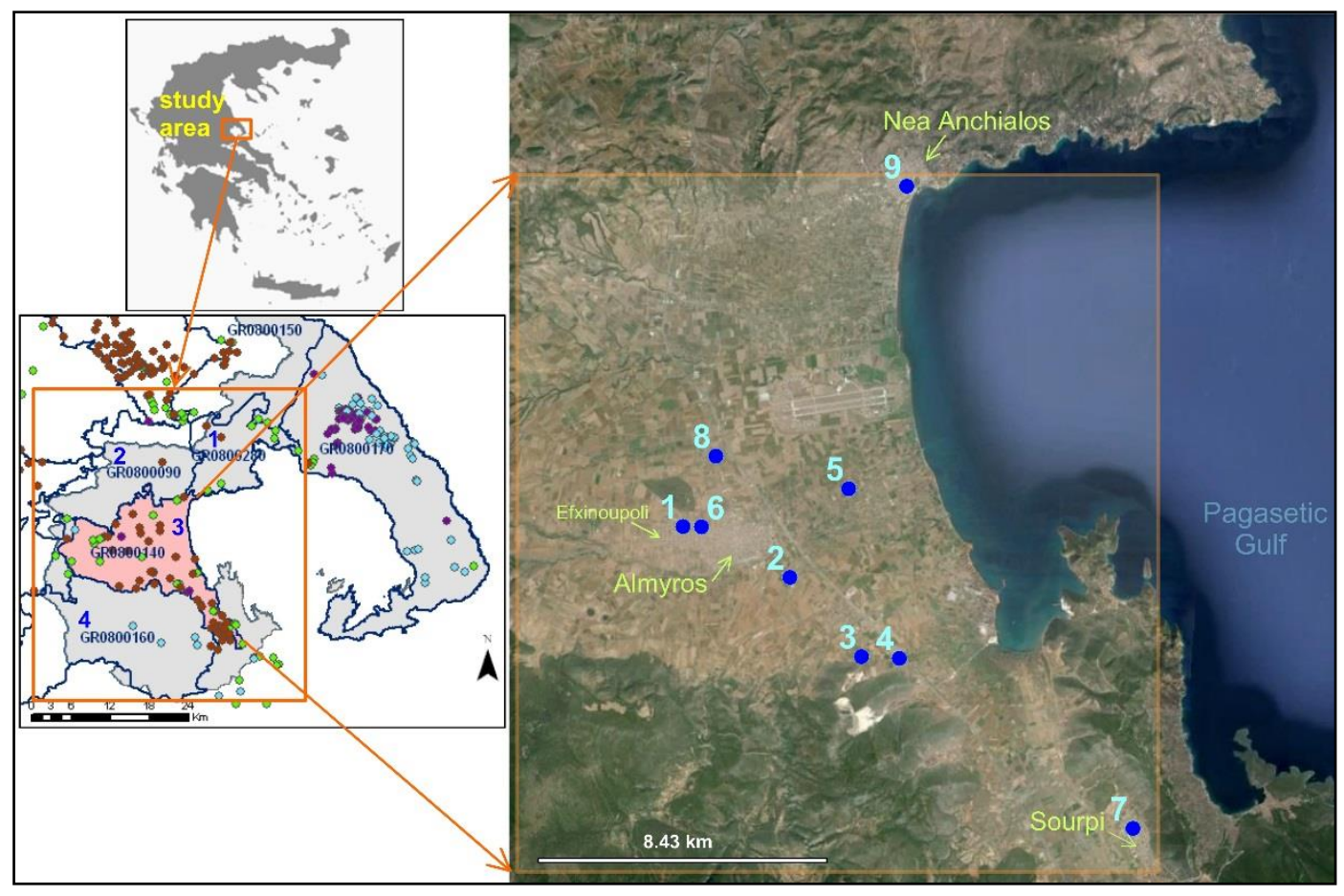

Figure 1 - Left: the study area of Almyros basin, the aquifer systems 1, 2, 3, 4. Right: Almyros coastal aquifer system (GR0800140) (MEECC, 2014b, modified), monitoring points for groundwater quality measurements (March and August 2013, April and September 2014) (background: Google earth 2015).

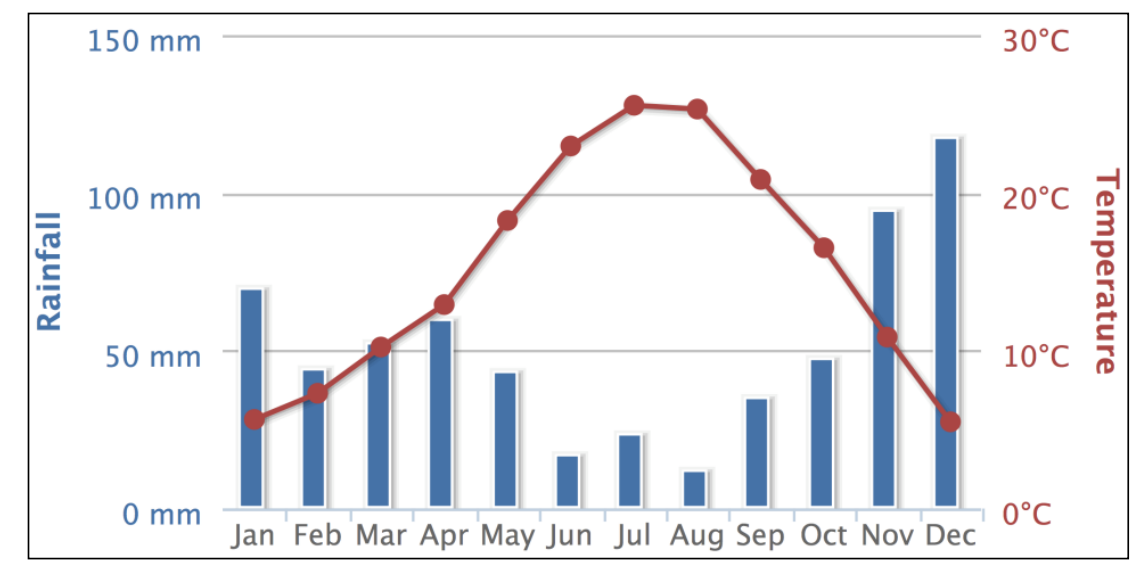

Figure 2 - Mean monthly temperature and rainfall values at the site of Almyros town for the time period 1990 - 2012 (http://sdwebx.worldbank.org/climateportal/).

The values of transmissivity $\mathrm{T}$ range between $8.0 \times 10^{-4}-1.2 \times 10^{-2} \mathrm{~m}^{2} / \mathrm{s}$ with the mean value being $2.3 \times 10^{-3} \mathrm{~m}^{2} / \mathrm{s}$. Also, the hydraulic conductivity $\mathrm{K}$ values vary between $7.9 \times 10^{-6}-2.5 \times 10^{-4} \mathrm{~m} / \mathrm{s}$ with the average value being $6.7 \times 10^{-5} \mathrm{~m} / \mathrm{s}$. Regarding the carbonate formations, the values of transmissivity range between $1.2 \times 10^{-4}-2.6 \times 10^{-1} \mathrm{~m} / \mathrm{s}$ with the average value being $2.9 \times 10^{-2} \mathrm{~m} / \mathrm{s}$ (Myriounis, 2008). 


\section{Materials and Methods}

\subsection{Hydrochemical research}

Seawater intrusion phenomena are observed in the margins of the Efxinoupoli sub-basin and the coastal and central part of the Sourpi sub-basin, which are areas adjacent to the brackish karstic aquifers of the region. The non-appearance of salinization phenomena in the central part of Efxinoupoli can be explained both by the state of hydraulic head and the given geological stratigraphic and tectonic conditions in the region (Myriounis, 2008).

Table 1 presents the min and max hydrochemical values of the aquifer systems (A.S.) of AlmyrosVelestino, Almyros and Orthrys for the mentioned time periods according to the measurements of $\operatorname{MEECC~(2014c).~}$

Table 1 - Min and max hydrochemical values at the aquifer systems (A.S.) of AlmyrosVelestino, Almyros and Orthrys for the mentioned time periods (MEECC, 2014c, modified).

\begin{tabular}{|l|c|c|c|}
\cline { 2 - 4 } \multicolumn{1}{c|}{} & Almyros-Velestino A.S. & Almyros A.S. & Orthrys A.S. \\
\cline { 2 - 4 } \multicolumn{1}{c|}{} & $2004-2008$ & $2004-2007$ & $1997-2008$ \\
\hline $\begin{array}{l}\text { Electrical Conductivity } \\
\mathrm{EC}(\mu \mathrm{S} / \mathrm{cm})\end{array}$ & $520.93-736.67$ & $258.5-966.3$ & $700.7-3894$ \\
\hline $\begin{array}{l}\text { Chloride }\left(\mathrm{Cl}^{-}\right) \\
\text {concentration }(\mathrm{mg} / \mathrm{L})\end{array}$ & $10.67-82.97$ & $17-578.7$ & $16.5-934.15$ \\
\hline $\begin{array}{l}\text { Nitrate }\left(\mathrm{NO}_{3}{ }^{-}\right) \\
\text {concentration }(\mathrm{mg} / \mathrm{L})\end{array}$ & $17.66-38.67$ & $7.9-55.1$ & $9.32-31$ \\
\hline
\end{tabular}

Based on MEECC (2014a), the iron (Fe) content values exceed in several points the maximum admissible concentration values in the northern part of Sourpi sub-basin and the central part basin of Almyros sub-basin. The nickel (Ni) content values are above the threshold in the northern part of Sourpi sub-basin and the central part of the basin. Above threshold is the lead $(\mathrm{Pb})$ content in the central part of the basin and close to the northern part of the Sourpi sub-basin. Furthermore, contents above limit for cadmium (Cd) and up to the limit for arsenic (As) are found in the aforementioned locations. Regarding the antimony ( $\mathrm{Sb}$ ), concentrations of 10 and $20 \mathrm{mg} / \mathrm{L}$ are found to the west of the Efxinoupoli and Platanos settlements. Also, increased nitrate concentrations $\left(\mathrm{NO}_{3}\right)$ in the groundwater are observed to the south of N. Anchialos town and to the west of Efxinoupoli town, respectively, which are attributed to fertilizer use in the farm soils (Lyra, 2015; MEECC, 2014a; Myriounis, 2008).

Under the current legislative framework, the qualitative status of the Almyros aquifer system is classified as poor. The salinization phenomenon is a permanent one in this region and is due to the overexploitation of groundwater to meet drinking and irrigation water needs. In the case of the Othrys aquifer system, which recharges the Almyros aquifer system, salinization is geologically originated (MEECC, 2014b; Myriounis, 2008).

\subsection{Recent hydrochemical data}

In the framework of a relative hydrogeological survey in the area of Almyros A.S. (figure 1), an updating of the qualitative parameters of the groundwater system, in the study area took place. In fact, sampling of groundwater in 9 selected wells was conducted and the appropriate chemical analyses were performed by the local private chemical laboratories "Parmakli", in March and August 2013 and in April and September of 2014 (Lyra, 2015). In Table 2, the values that exceed the maximum permitted or acceptable suitability limits for drinking water are presented. 
Table 2 - Hydrochemical values at Almyros A.S. indicating with bold typing values that exceed the maximum permitted or acceptable limits for drinking water - time periods A: March 2013, B: August 2013, C: April 2014, D: September 2014 (Government Gazette-GG 630, 26-4-2007, GG 2075, 25-9-2009, GG 3322, 30-12-2011, Kallergis, 2000) (figure 1).

\begin{tabular}{|c|c|c|c|c|c|c|c|c|c|c|}
\hline \multicolumn{2}{|c|}{ well $\rightarrow$} & 1 & 2 & 3 & 4 & 5 & 6 & 7 & 8 & 9 \\
\hline \multirow{4}{*}{$\begin{array}{l}\mathrm{Na}^{+} \\
(>200 \\
\mathrm{mg} / \mathrm{L})\end{array}$} & $\mathrm{A}$ & 50 & 50 & 150 & $>250$ & 50 & 50 & 75 & 75 & 50 \\
\hline & $\mathrm{B}$ & 50 & 50 & 175 & $>250$ & 50 & 50 & 75 & 75 & 50 \\
\hline & $\mathrm{C}$ & 45 & 40 & 125 & 175 & 40 & 25 & 40 & 75 & 40 \\
\hline & $\mathrm{D}$ & 100 & 75 & 200 & $>250$ & 100 & 75 & 75 & 100 & 75 \\
\hline \multirow{4}{*}{$\begin{array}{l}\mathrm{NO}_{3}^{-} \\
(>50 \\
\mathrm{mg} / \mathrm{L})\end{array}$} & $\mathrm{A}$ & 45.3 & 80 & 10 & 6 & 95 & 33.6 & 30.5 & 25 & 20 \\
\hline & B & 56.7 & 97.6 & 12.3 & 7.37 & 110 & 45.8 & 36.5 & 25.8 & 22.9 \\
\hline & $\mathrm{C}$ & 32.5 & 49.5 & 18 & 15 & 85 & 30.7 & 25.5 & 20 & 17.5 \\
\hline & $\mathrm{D}$ & 65 & 72 & 65 & 110 & 120 & 65 & 42 & 28 & 22 \\
\hline \multirow{4}{*}{$\begin{array}{l}\mathrm{Ca}^{2+} \\
(>100 \\
\mathrm{mg} / \mathrm{L})\end{array}$} & $\mathrm{A}$ & 60 & 62 & 100 & 120 & 76 & 60 & 66 & 70 & 60 \\
\hline & $\mathrm{B}$ & 62 & 70 & 112 & 124 & 80 & 62 & 70 & 74 & 62 \\
\hline & $\mathrm{C}$ & 58 & 56 & 82 & 90 & 70 & 54 & 60 & 60 & 58 \\
\hline & $\mathrm{D}$ & 82 & 84 & 94 & 122 & 88 & 70 & 84 & 50 & 60 \\
\hline \multirow{4}{*}{$\begin{array}{c}\mathrm{Cl}^{-} \\
(>250 \\
\mathrm{mg} / \mathrm{L})\end{array}$} & $\mathrm{A}$ & 53.2 & 53.2 & 159.5 & 283.6 & 70.9 & 53.2 & 62 & 70.9 & 44.3 \\
\hline & $\mathrm{B}$ & 70.9 & 70.9 & 180.8 & 303.1 & 78 & 70.9 & 88.6 & 88.6 & 53.2 \\
\hline & $\mathrm{C}$ & 44.3 & 44.3 & 97.5 & 212.7 & 62 & 35.5 & 51.4 & 53.2 & 35.5 \\
\hline & $\mathrm{D}$ & 88.6 & 79.8 & 141.8 & 336.8 & 79.8 & 70.9 & 106.4 & 70.9 & 44.3 \\
\hline \multirow{4}{*}{$\begin{array}{c}\mathrm{EC} \\
(>2500 \\
\mu \mathrm{S} / \mathrm{cm})\end{array}$} & $\mathrm{A}$ & 825 & 810 & 1950 & 2250 & 910 & 810 & 974 & 1050 & 880 \\
\hline & B & 872 & 846 & 2213 & 3476 & 953 & 845 & 1050 & 1100 & 920 \\
\hline & $\mathrm{C}$ & 885 & 730 & 1450 & 2210 & 799 & 690 & 788 & 910 & 780 \\
\hline & $\mathrm{D}$ & 1100 & 850 & 1950 & 3300 & 1100 & 950 & 890 & 1300 & 950 \\
\hline
\end{tabular}

\subsection{Application of the DSIR framework}

The DPSIR framework/model has been developed in the late 1990s and was proposed by the Organization for Economic Cooperation and Development (OECD, 2003) as a methodology for structuring and organizing of varying type indicators/indexes in a way comprehensible for decision makers. It was based on previous methodologies within an environmental context and was adopted as a conceptual framework by the European Environment Agency (EEA) in 1995 (Gabrielson and Bosch, 2003). The DPSIR has been developed to express a cause - effect relationship between environmental and human systems. The DPSIR model can be used as an analytical tool for the study of water issues. It enables a comprehensive assessment of the issues through the examination of the relevant Driving forces (causes) and Pressures (pollutants) on the environment, the subsequent State (quality) of the environment as represented by its Impacts (health, ecosystems), Responses (policies, targets) and interfaces among its elements (Kristensen, 2004). Implementation cases of DPSIR framework regarding water issues exist in the international and Greek literature (Agyemang et al., 2007; Caeiro et al., 2004; Chung et al., 2011; Karageorgis et al., 2005; Lin et al., 2007; Ntislidou et al., 2011).

Towards implementing the DPSIR framework in the study area, the sequence of pressures, states, impacts and responses engaged to each driver is presented (Lyra, 2015), as it is derived from the accordance with the DPSIR methodology (Table 1), taking, also, into account relevant data from the River Basin Management Plan of Thessaly Water District (GR08) (MEECC, 2014a), and few ones from the theses of Chouliaras (2014), Lyra (2015) and Myriounis (2008). The driving forces taken into consideration for the study area, are as follows (Table 2): (1) Population, (2) Climate, (3) Land use, (4) Protected areas, (5) Topography, (6) Geology, (7) Urban Development (8) Agricultural activity (9) Industrial activity and (10) Legislative framework. 
Table 3 - Summarized presentation of main findings resulting from the implementation of the DPSIR framework in the coastal part of Almyros Basin, Magnesia Prefecture, Greece (Lyra, 2015, modified).

\begin{tabular}{|c|c|c|}
\hline \multirow{5}{*}{1} & $\begin{array}{l}\text { DRIVING } \\
\text { FORCE }\end{array}$ & Population \\
\hline & PRESSURE & $\begin{array}{l}\text { - Rural population growth during 1991-2001 } \rightarrow \text { quality and quantity of } \\
\text { water resources }\end{array}$ \\
\hline & STATE & $\begin{array}{l}\text { - Overexploitation of the groundwater system } \\
\text { - Poor quantitative and qualitative state of groundwaters }\end{array}$ \\
\hline & IMPACT & - Increase of pollutants from human activities \\
\hline & RESPONSE & $\begin{array}{l}\text { - Improvement-updating of infrastructure for meeting the needs regarding } \\
\text { drinking water supply, irrigation, sewage networks, wastewaters and } \\
\text { solid-wastes treatment plants }\end{array}$ \\
\hline \multirow{5}{*}{2} & $\begin{array}{l}\text { DRIVING } \\
\text { FORCE }\end{array}$ & Climate \\
\hline & PRESSURE & $\begin{array}{l}\text { - Agricultural plant species } \\
\text { - Qualitative identity of groundwater } \\
\text { - Quantitative identity of groundwater }\end{array}$ \\
\hline & STATE & - Influence of ecosystems \\
\hline & IMPACT & $\begin{array}{l}\text { - Change in agricultural productivity } \\
\text { - Increase in costs of agricultural production } \\
\text { - Reduced recharge of water systems } \\
\text { - Increase in pollution loads } \\
\text { - Desertification, floods }\end{array}$ \\
\hline & RESPONSE & $\begin{array}{l}\text { - Modernization of legislation, enactment and implementation of measures } \\
\text { in respect of environmental protection and risk management }\end{array}$ \\
\hline \multirow{5}{*}{3} & $\begin{array}{l}\text { DRIVING } \\
\text { FORCE }\end{array}$ & Land use \\
\hline & PRESSURE & $\begin{array}{l}\text { - Quantity of groundwater resources } \\
\text { - Quality of groundwater resources: use of soil improvers and pesticides }\end{array}$ \\
\hline & STATE & $\begin{array}{l}\text { - Poor quantitative status of groundwater resources } \\
\text { - Poor chemical condition of groundwater resources }\end{array}$ \\
\hline & IMPACT & - Eradication of artesian phenomena and submarine springs \\
\hline & RESPONSE & $\begin{array}{l}\text { - Drilling of new wells and deepening of existing ones towards finding } \\
\text { suitable drinking and irrigation water } \\
\text { - Construction of a water reservoir in Xeria, Almyros }\end{array}$ \\
\hline
\end{tabular}


Table 3 (continued). Summarized presentation of main findings resulting from the implementation of the DPSIR framework in the coastal part of Almyros Basin, Magnesia Prefecture, Greece (Lyra, 2015, modified).

\begin{tabular}{|c|c|c|}
\hline \multirow{5}{*}{4} & $\begin{array}{l}\text { DRIVING } \\
\text { FORCE }\end{array}$ & Protected areas \\
\hline & PRESSURE & - Impediment for anthropogenic and tourist activities \\
\hline & STATE & $\begin{array}{l}\text { - Protected environment to polluting events } \\
\text { - Ensured qualitative status of groundwater resources }\end{array}$ \\
\hline & IMPACT & $\begin{array}{l}\text { - Influence redistribution of productivity sectors of the local economy } \\
\text { - Change of employment tasks and workload in each productivity sector }\end{array}$ \\
\hline & RESPONSE & $\begin{array}{l}\text { - Agricultural development } \\
\text { - Decrease of human resources in touristic activities }\end{array}$ \\
\hline \multirow{5}{*}{5} & $\begin{array}{l}\text { DRIVING } \\
\text { FORCE }\end{array}$ & Topography \\
\hline & PRESSURE & $\begin{array}{l}\text { - Lack of major rivers } \\
\text { - Hydrographic network } \rightarrow \text { soil erosion } \\
\text { - Relative morphological lowering of the eastern compared to western part } \\
\text { - Siltation towards the coast }\end{array}$ \\
\hline & STATE & $\begin{array}{l}\text { - Intense deep down erosion of the streams } \\
\text { - Escalated progress of bank erosion in watercourses beds }\end{array}$ \\
\hline & IMPACT & $\begin{array}{l}\text { - Deposition of sediment at the coast of reduced mechanical strength and } \\
\text { increased vulnerability to salinization phenomena }\end{array}$ \\
\hline & RESPONSE & - No influence on the environment and the primary productivity sector \\
\hline \multirow{5}{*}{6} & $\begin{array}{l}\text { DRIVING } \\
\text { FORCE }\end{array}$ & Geology \\
\hline & PRESSURE & $\begin{array}{l}\text { - Water balance (runoff, infiltration) } \\
\text { - Qualitative status of aquifer systems } \\
\text { - Agricultural plant species and productivity of land soils } \\
\text { - Infiltration into the alluvial aquifer of nitrogen compounds }\end{array}$ \\
\hline & STATE & $\begin{array}{l}\text { - Dredging and drilling of wells meeting the needs for water supply and } \\
\text { irrigation purposes } \\
\text { - Hydraulic connection of the coastal area with the sea } \\
\text { - Salinization due to the mineralogical character of the bedrock }\end{array}$ \\
\hline & IMPACT & $\begin{array}{l}\text { - } \mathrm{pH} \text { and soil suitability alteration as regards the agricultural exploitation, } \\
\text { due to brackish water irrigation use } \\
\text { - Declining course of primary productivity sector } \\
\text { - Deterioration of salinization phenomena in the aquifer systems }\end{array}$ \\
\hline & RESPONSE & $\begin{array}{l}\text { - Drilling of new wells and deepening of existing ones } \\
\text { - Overexploitation of aquifers }\end{array}$ \\
\hline
\end{tabular}


Table 3 (continued). Summarized presentation of main findings resulting from the implementation of the DPSIR framework in the coastal part of Almyros Basin, Magnesia Prefecture, Greece (Lyra, 2015, modified).

\begin{tabular}{|c|c|c|}
\hline \multirow{5}{*}{7} & $\begin{array}{l}\text { DRIVING } \\
\text { FORCE }\end{array}$ & Urban development \\
\hline & PRESSURE & $\begin{array}{l}\text { - Wastes } \\
\text { - Quality of surface waters } \rightarrow \text { Impact on Xirorema stream } \\
\text { - Quality of groundwater } \rightarrow \text { Use of underground sewage treatment } \\
\text { infrastructures where there is a lack of sewerage networks } \\
\text { - Uncontrolled waste disposal }\end{array}$ \\
\hline & STATE & $\begin{array}{l}\text { - Increased concentrations of nitrogenous compounds, organic carbon, } \\
\text { phosphorus compounds and unknown polluting substances for } \\
\text { environmental absorption }\end{array}$ \\
\hline & IMPACT & $\begin{array}{l}\text { - Qualitative deterioration of surface and groundwater bodies } \\
\text { - Ecological degradation of the environment }\end{array}$ \\
\hline & RESPONSE & $\begin{array}{l}\text { - Improvement and creation of sewage and waste treatment infrastructure } \\
\text { services for civil population } \\
\text { - Modernization of waste disposal legislation } \\
\text { - Integrated record of areas for treated wastewater disposal through } \\
\text { irrigation or artificial recharge } \\
\text { - Specification of water-extraction limit criteria per water system }\end{array}$ \\
\hline \multirow{5}{*}{8} & $\begin{array}{l}\text { DRIVING } \\
\text { FORCE }\end{array}$ & Agricultural Activity \\
\hline & PRESSURE & $\begin{array}{l}\text { - Quantitative and qualitative status of groundwater resources } \\
\text { - Use of chemical fertilizers and pesticides } \\
\text { - Untreated livestock wastewater/sludge }\end{array}$ \\
\hline & STATE & $\begin{array}{l}\text { - Increased concentration of nitrogen, phosphorus and organic carbon in } \\
\text { Lachanorema and Cholorema streams }\end{array}$ \\
\hline & IMPACT & $\begin{array}{l}\text { - Deterioration of quality level of both surface water and groundwater } \\
\text { systems }\end{array}$ \\
\hline & RESPONSE & $\begin{array}{l}\text { - Advancement of livestock farming waste and agricultural effluent } \\
\text { treatment facilities } \\
\text { - Gradual alteration of conventional farming to biological } \\
\text { - Specification of water-extraction limit criteria per water system } \\
\text { - Rational use of fertilizers and water in nitrate vulnerable zones }\end{array}$ \\
\hline
\end{tabular}

\section{Conclusions}

Salinization and pollution phenomena are caused by the overexploitation of water resources in Almyros Basin. The implementation of the DPSIR framework provided evidence contributing to further raising the awareness concerning the status of the urban and natural environment. Two discrete benefits for the area were indicated: (a) recognition of the problems resulted from the interference of the human factor to satisfy survival needs and (b) provision of direction of recommended action to be taken towards a more effective management of water resources. 
Table 3 (continued). Summarized presentation of main findings resulting from the implementation of the DPSIR framework in the coastal part of Almyros Basin, Magnesia Prefecture, Greece (Lyra, 2015, modified).

\begin{tabular}{|c|c|c|}
\hline & $\begin{array}{l}\text { DRIVING } \\
\text { FORCE }\end{array}$ & Industrial activity \\
\hline & PRESSURE & $\begin{array}{l}\text { - Quarrying } \\
\text { - Mining } \\
\text { - Use of soil reservoirs } \\
\text { - Uncontrolled, unplanned and unauthorized disposal of industrial } \\
\text { wastewater }\end{array}$ \\
\hline & STATE & $\begin{array}{l}\text { - Alteration of morphology } \\
\text { - Unknown pollutants in soil } \\
\text { - Poor chemical status of aquifer system }\end{array}$ \\
\hline 9 & IMPACT & $\begin{array}{l}\text { - Deterioration of the quality of groundwater } \\
\text { - Deterioration of the quality of Platanorema stream } \\
\text { - Increase of operating load at the WWTP } \\
\text { - Change in microclimate } \\
\text { - Increase of flooding } \\
\text { - Intensified erosion and deposition of sediment/flood debris }\end{array}$ \\
\hline & RESPONSE & $\begin{array}{l}\text { - Defining conditions and requirements for connecting industries to the } \\
\text { sewage system and the WWTP } \\
\text { - Modernization of industrial waste management legislation } \\
\text { - Institutional framework for the licensing of sewage tanker vehicles } \\
\text { - Integration of industrial units in program of environmental authorization } \\
\text { and control }\end{array}$ \\
\hline \multirow[b]{5}{*}{10} & $\begin{array}{l}\text { DRIVING } \\
\text { FORCE }\end{array}$ & - Legislative framework \\
\hline & PRESSURE & $\begin{array}{l}\text { - Preventing the worsening of environmental degradation of groundwater } \\
\text { - Protection of aquifer systems }\end{array}$ \\
\hline & STATE & - Degraded quantitative and qualitative status of Almyros system \\
\hline & IMPACT & $\begin{array}{l}\text { - Qualitative and quantitative deficit of exploitable water to meet drinking } \\
\text { and irrigation water needs }\end{array}$ \\
\hline & RESPONSE & $\begin{array}{l}\text { - Establishment of pollutant emission limits at watershed level } \\
\text { - Updating of the decision } \Phi 16 / 6631 / 1989 \text { setting the lower and upper } \\
\text { limits for the necessary water quantities for irrigation purposes } \\
\text { - Prohibition of new water projects and expansion of water use permits in } \\
\text { underground systems with poor quantitative status } \\
\text { - Water extraction record instrumentation } \\
\text { - Legislative framework establishment for the protection of groundwater } \\
\text { systems }\end{array}$ \\
\hline
\end{tabular}




\section{References}

Agyemang, I., McDonald, A. and Carver, S., 2007. Application of the DPSIR framework to environmental degradation assessment in northern Ghana, Nat. Resour. Forum, 31, 212-225.

Caeiro, S., Mourão, I., Costa, M.H., Painho, M., Ramos, T.B. and Sousa, S., 2004. Application of the DPSIR model to the Sado Estuary in a GIS context - Social and Economical Pressures, "7th AGILE Conference on Geographic Information Science" 29 April-1May 2004, Heraklion, Greece.

Chouliaras, G., 2014. Longitudinal Changes in the Natural and Human Environment Almyros area. Triggering Mechanisms of Evolution and Relationship with Sustainability, PhD Thesis, Laboratory of Mineralogy and Geology, Division of Geological Science and Atmospheric Environment, Agricultural University of Athens, Greece, $282 \mathrm{pp}$.

Chung, E.S., Hong, W.P., Lee, K.S. and Burian, S.J., 2011. Integrated Use of a Continuous Simulation Model and Multi-Attribute Decision-Making for Ranking Urban Watershed Management Alternatives, Water Resour Manage, 25, 641-659.

Gabrielson, P. and Bosch, P., 2003. Environmental indicators: typology and use in reporting. In: Internal Working Paper, European Environmental Agency, 1-20. Available at: http://sdwebx.worldbank.org/climateportal/index.cfm?page=country_historical_climate \& ThisRegion $=$ Europe $\&$ This CCode = GRC (last access date: $5-4-2016$ ).

Kallergis, G., 2000. Applied - Environmental Hydrogeology, Volume B, published TCG, Athens, 345 pp. (in Greek).

Karageorgis, A.P., Skourtos, M.S., Kapsimalis, V., Kontogianni, A.D., Skoulikidis, N.Th., Pagou, K., Nikolaidis, N.P., Drakopoulou, P., Zanou, B., Karamanos, H., Levkov, Z. and Anagnostou, Ch., 2005. An integrated approach to watershed management within the DPSIR framework: Axios River catchment and Thermaikos Gulf, Reg. Environ. Change J., 5, 138160.

Kristensen, P., 2004. The DPSIR Framework. Paper presented at the 27-29 September 2004 workshop on a comprehensive / detailed assessment of the vulnerability of water resources to environmental change in Africa using river basin approach, UNEP Headquarters, Nairobi, Kenya.

Lin, T., Xue, X.Z. and Lu, C.Y., 2007. Analysis of Coastal Wetland Changes Using the "DPSIR" Model: A Case Study in Xiamen, China, Coastal Management, 35, 289-303.

Lyra, A., 2015. Water resources and DPSIR framework. The case study of the coastal part of Almyros basin, Magnesia Prefecture, Diploma Thesis, Department of Civil Engineering, Democritus University of Thrace, Xanthi, Greece.

MEECC - Ministry of Environment, Energy and Climate Change (Special Secretariat for Water), 2014a. River Basin Management Plan of Thessaly Water District (GR08).

MEECC - Ministry of Environment, Energy and Climate Change (Special Secretariat for Water), 2014b. River Basin Management Plan of Thessaly Water District (GR08). Analysis of anthropogenic pressures and their impact on surface water systems and aquifer systems.

MEECC - Ministry of Environment, Energy and Climate Change (Special Secretariat for Water), 2014c. River Basin Management Plan of Thessaly Water District (GR08). Assessment and classification of quality (chemical) and quantitative status of aquifer systems.

Mentzafou, A., 2004. Hydrogeological conditions of Almyros basin, Volos, MSc Thesis, National Technical University of Athens, Greece.

Myriounis, C., 2008. Hydrogeological and hydrochemical research of groundwater in the coastal part of the hydrological basin of Almyros, Magnesia Prefecture, PhD Thesis, School of Geology, Faculty of Sciences, Aristotle University of Thessaloniki, Greece, 424 pp.

Ntislidou, C., Basdeki, A., Papacharalampou, Ch., Albanakis, K., Lazaridou, M. and Voudouris K., 2011. Interdisciplinary Postgraduate Study Program "Ecological Water Quality and Management at a River Basin Level” Departments of Biology, Geology \& Civil Engineering, Aristotle University of Thessaloniki, Thessaloniki, Greece. 